\title{
Mass coral bleaching in the northern Persian Gulf, 2012
}

\author{
Javid Kavousi ${ }^{1}$, Parviz Tavakoli-Kolour ${ }^{2}$, Maria Mohammadizadeh ${ }^{3}$, Arezoo Bahrami ${ }^{2}$, \\ Abbas Barkhordari ${ }^{2}$ \\ ${ }^{1}$ Graduate School of Engineering and Science, University of the Ryukyus, 1 Senbaru, Nishihara 903-0213, Okinawa, Japan. \\ E-mail: javid.kavousi@gmail.com \\ ${ }^{2}$ Young Researchers and Elits Club, Bandar Abbas Branch, Islamic Azad University, PO Box 79159-14 1311, \\ Bandar Abbas, Iran. \\ ${ }^{3}$ Department of Environmental Management, Islamic Azad University, Bandar Abbas Branch, PO Box 79159-1311, \\ Bandar Abbas, Iran.
}

\begin{abstract}
Summary: Coral bleaching events due to elevated temperatures are increasing in both frequency and magnitude worldwide. Mass bleaching was recorded at five sites in the northern Persian Gulf during August and September 2012. Based on available seawater temperature data from field, satellite and previous studies, we suggest that the coral bleaching threshold temperature in the northern Persian Gulf is between 33.5 and $34^{\circ} \mathrm{C}$, which is about 1.5 to $2.5^{\circ} \mathrm{C}$ lower than that in the southern part. To assess the bleaching effects, coral genera counted during 60-minute dives were categorized into four groups including healthy, slightly bleached ( $<50 \%$ bleached tissue), mostly bleached ( $>50 \%$ bleached tissue) and fully bleached colonies The anomalously high sea surface temperature resulted in massive coral bleaching ( 84\% coral colonies affected). Acropora spp. colonies, which are known as the most vulnerable corals to thermal stress, were less affected by the bleaching than massive corals, such as Porites, which are among the most thermo-tolerant corals. Turbid waters, suggested as coral refugia against global warming, did not protect corals in this study since most affected corals were found in the most turbid waters. The 2012 bleaching in the northern Persian Gulf was relatively strong from the viewpoint of coral bleaching severity. Longterm monitoring is needed to understand the actual consequences of the bleaching event on the coral reefs and communities.
\end{abstract}

Keywords: coral bleaching; thermal threshold; Iranian islands; Persian Gulf.

Evento de blanqueamiento masivo en la zona norte del Gofo Pérsico, 2012

Resumen: Los eventos de blanqueamiento de corales están aumentando en frecuencia y magnitud debido al aumento de la temperatura en los océanos. En este trabajo se describe un evento de blanqueamiento masivo observado en seis localidades del norte del Golfo Pérsico entre Agosto y Septiembre de 2012. Los datos de temperatura disponibles, medidas in situ y observaciones de satélites de la temperatura de la superficie del mar, sugieren que la temperatura umbral que desencadena el blanqueo de coral en el norte del Golfo Pérsico corresponde a una temperatura de entre $33,5-34^{\circ} \mathrm{C}$ que es una temperatura entre 1.5 a $2.5^{\circ} \mathrm{C}$ inferior a la observada en las zonas más meridionales del Golfo Persico $\left(35-36^{\circ} \mathrm{C}\right)$. Para la evaluación de los efectos de blanqueo sobre las comunidades de coral, se realizaron transectos de 60 minutos entre 0 y 6 m de profundidad. Durante las inmersiones cada colonia de coral se identificó a nivel de género y su estado se asignó a una de las siguientes categorías: no afectada, ligeramente afectada $(<50 \%$ del tejido blanqueado), severamente afectada ( $>50 \%$ del tejido blanqueado) y colonias totalmente afectadas ( $100 \%$ del tejido blanqueado). El análisis de los datos de temperatura permitió identificar una anomalía térmica durante el periodo de blanqueamiento que afectó a un $84 \%$ de las colonias censadas. Contrariamente a otros eventos de blanqueamiento analizados, las colonias de Acropora spp., que se encuentran entre las especies más vulnerables al estrés térmico, fueron menos afectadas que las especies de corales masivos como Porites spp. que normalmente presentan una gran resistencia al estrés térmico. Igualmente a pesar que la turbidez de las aguas ha sido señalada como un factor protector en el contexto del calentamiento global, en nuestro estudio observamos que las zonas más afectadas por el blanqueamiento presentaban las tasas de turbidez más elevadas. En conclusión el evento de blanqueamiento de 2012 observado en el norte del Golfo Pérsico afectó severamente a las comunidades de coral. El seguimiento a largo plazo de las comunidades de coral se presenta como una necesidad para comprender las consecuencias de los eventos de blanqueamiento.

Palabras clave: blanqueamiento de corales; termotolerancia; Islas Iranies; Golfo Pérsico.

Citation/Como citar este artículo: Kavousi J., Tavakoli-Kolour P., Mohammadizadeh M., Bahrami A., Barkhordari A. 2014. Mass coral bleaching in the northern Persian Gulf, 2012. Sci. Mar. 78(3): 397-404. doi: http://dx.doi.org/10.3989/ scimar.03914.16A

Editor: J. Garrabou.

Received: June 26, 2013. Accepted: May 28, 2014. Published: July 16, 2014.

Copyright: (C) 2014 CSIC. This is an open-access article distributed under the Creative Commons Attribution-Non Commercial Lisence (by-nc) Spain 3.0. 


\section{INTRODUCTION}

Coral bleaching, loss of symbiotic algae (zooxanthellae) and/or their photosynthetic pigments by zooxanthellate reef-builders is considered a major threat for coral reefs worldwide (Lesser 2011), especially because large-scale bleaching events have been related to global warming (Goreau and Hayes 1994, 2005). Mortality related to coral bleaching has caused global decline in coral cover (Goreau et al. 2005, Wilkinson 2008) and local extinction of several species (Riegl 2002, Sheppard 2006).

Coral bleaching events have increasingly affected coral reefs on a global scale in recent years (Goreau and Hayes 1994, 2005, Coles and Brown 2003, Meissner et al. 2012). Bleaching can be predicted with high accuracy when seawater temperature anomalies exceed $1{ }^{\circ} \mathrm{C}$ above the maximum normal monthly average summer temperature for one month; its severity increases according to the extent and duration of the anomaly (Goreau and Hayes 1994, 2005). For example, a 3-4 ${ }^{\circ} \mathrm{C}$ temperature anomaly for a few days can lead to coral death (Buchheim 2005).

The most destructive global coral bleaching events reported have occurred worldwide in the last three decades (Goreau and Hayes 1994, 2005, Goreau et al. 2000, Wilkinson 2004, 2008, Riegl et al. 2011, Guest et al. 2012), including in the Persian Gulf (Rezai et al. 2004, Riegl and Purkis 2009, Riegl et al. 2011).

The Persian Gulf, a semi-closed sea (Fig. 1), is known as one of the most extreme environments for coral reefs, with high salinity (up to $>39 \mathrm{psu}$ ), high sea surface temperature fluctuations from $12^{\circ} \mathrm{C}$ in winter (Sheppard et al. 1992) to $38^{\circ} \mathrm{C}$ in summer (Baker et al. 2004), a high sedimentation rate and low water circulation, particularly in the southern part of the Gulf (Riegl and Purkis 2012). The Persian Gulf is considered the hottest coral sea in the world. Temperature conditions associated with coral bleaching in the Persian Gulf are higher than in any other region in the world (Goreau and Hayes 1994, 2005, Sheppard 2003), so some corals in the Persian Gulf can stand summer temperatures up to $10^{\circ} \mathrm{C}$ higher than corals elsewhere (Coles and Riegl 2013). Nevertheless, the coral reefs in the Persian Gulf are also vulnerable to temperature anomalies and their long-term impacts (Burt et al. 2011).

This paper studies the spatial variation in bleaching susceptibility of corals from some Iranian islands in the northern and central Persian Gulf during a coral bleaching event observed in 2012. To this end, we examined the responses of coral communities and reefs based on the bleaching status of individual colonies (i.e. fully bleached, mostly bleached, partially bleached or healthy). We also compared genus-specific responses. Moreover, from the analysis of temperature data sets available, we suggest 33.5 to $34^{\circ} \mathrm{C}$ as the coral bleaching threshold temperature in the northern Persian Gulf, which is about 1.5 to $2.5^{\circ} \mathrm{C}$ lower than the threshold suggested for the southern part of the Gulf $\left(35\right.$ to $\left.36^{\circ} \mathrm{C}\right)$. This work, which is the first quantitative assessment of a bleaching event in the northern Persian Gulf and Bu-Musa Island, provides valuable data which can be used as a baseline for studies on ecological and physiological changes in the coral communities and their responses to future bleaching events in this region.

\section{MATERIALS AND METHODS}

\section{Study sites}

Coral reefs at five sites around three Iranian islands of the northern Persian Gulf, Larak, Hormuz and Qeshm Islands, were assessed for effects of the high temperature anomalies recorded in late August and early September 2012. Bu-Musa Island, located in the central Persian Gulf, was investigated on October 6 and 7 (Fig. 1).

\section{Larak Island}

Two sites were chosen: L-NE in the northeast $\left(26^{\circ} 53^{\prime} \mathrm{N}, 56^{\circ} 23^{\prime} \mathrm{E}\right)$ and $\mathrm{L}-\mathrm{SW}$ in the southwest $\left(26^{\circ} 49^{\prime} \mathrm{N}, 56^{\circ} 18^{\prime} \mathrm{E}\right)$ of the island's main reefs. The site L-NE had $77.35 \%$ coral cover with Acropora as the dominant genus in 2006 (Rezai et al. 2010). However, in a survey carried out in 2010-2011 this site had only $5.69 \pm 0.54 \%$ coral cover, whereas site L-SW has $21.74 \pm 1.92 \%$ (Mohammadizadeh et al. 2013). These inter-site differences are attributed to differentially higher levels of stress at site L-NE, especially related to direct human activities (Mohammadizadeh et al. 2013). Both sites are near shore, with a maximum distribution depth of corals of 7 and $5 \mathrm{~m}$ at low tide at L-NW and L-NE, respectively (Mohammadizadeh et al. 2013), but depths between 3 and $5 \mathrm{~m}$ that included major coral reefs and communities were surveyed at both sites.

\section{Hormuz Island}

Two sites were sampled: H-RS to the south $\left(27^{\circ} 01^{\prime} \mathrm{N}, 5^{\circ} 27^{\prime} \mathrm{E}\right)$ and H-E $\left(27^{\circ} 03^{\prime} \mathrm{N}, 56^{\circ} 30^{\prime} \mathrm{E}\right)$ to the east of Hormuz Island. The depth range of corals at both sites is the same, less than $5 \mathrm{~m}$ with no clear slope. Therefore, the survey depth was similar to the depth range of the corals. These two sites display different coral cover and are subject to differential environmental conditions. Site H-RS is next to an iron mine, so its benthic communities are continuously exposed to fine organic sediment deposition. Benthic communities at this site are usually surrounded and/or covered by red iron particles, but are still viable. Horizontal visibility in some parts of this site ranges from less than 30 to $220 \mathrm{~cm}$. Dominant benthic communities are zoanthids, with $44 \pm 29 \%$ (mean \pm SD) cover, and isolated small coral colonies, with $4 \pm 6 \%$ (mean $\pm \mathrm{SD}$ ) (Kavousi et al. unpublished data).

Site H-E has stronger tidal currents than site H-RS. H-E comprises the main coral reefs and communities of Hormuz Island and has $60 \pm 16 \%($ mean \pm SD) and $8.68 \pm 7.0 \%($ mean $\pm \mathrm{SD})$ of the substratum covered by zoanthids and scleractinian corals, respectively (Kavousi et al. 2013). More than $85 \%$ of the reef-building corals at this site are massive Porites spp. No branching corals were observed at either Hormuz Island site. 


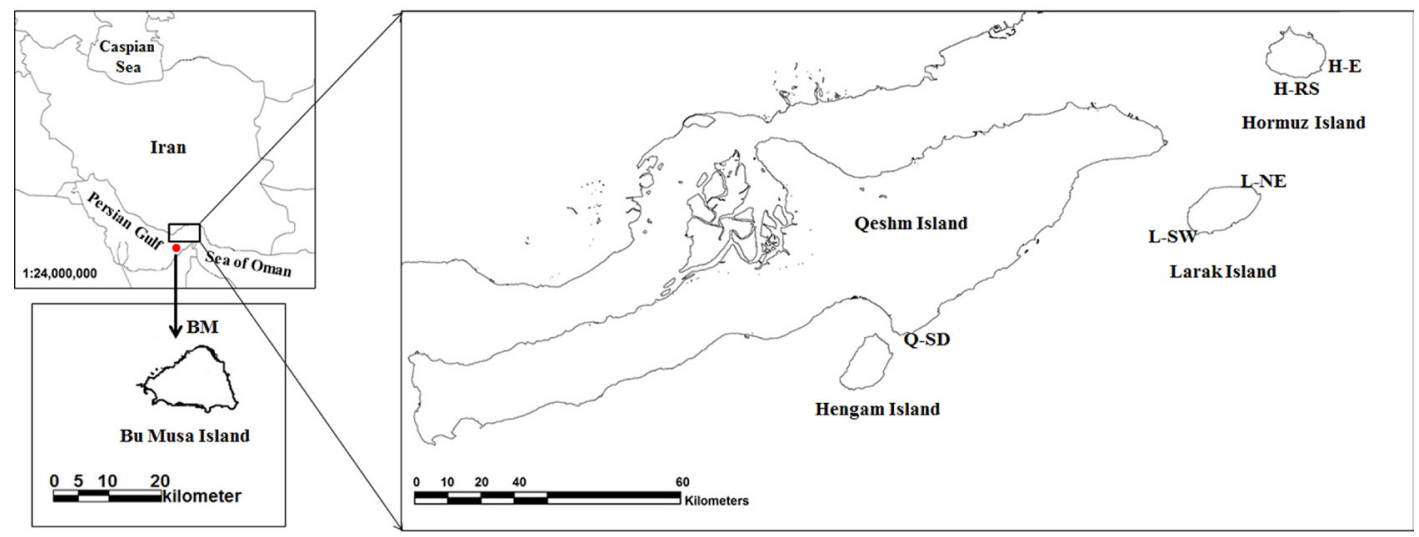

Fig. 1. - Map of sites examined in this study.

The sedimentation rate was $0.05 \pm 0.01 \mathrm{~g} \mathrm{~cm}^{-2}$ day $^{-1}$ at H-E (Kavousi et al. 2013) and it could not be measured at H-RS owing to lost sediment trapped at this site. However, rates at both sites were obviously much higher than those at other islands studied. Benthic communities at both sites are mostly covered by sediments, but are still alive. These conditions are permanent characteristics of these sites. These two sites encounter less direct human impact including diving and snorkeling activities than the other sites studied.

\section{Qeshm Island}

At Qeshm Island the site Shib-Deraz $\left(26^{\circ} 41^{\prime} \mathrm{N}\right.$, $55^{\circ} 56^{\prime} \mathrm{E}$; site Q-SD) harbouring one of its main coral community sites was studied. This site has $14.03 \pm 4.8 \%$ live coral cover but no true coral reefs are developed; instead, individual colonies of a few species are found (Kavousi et al. 2011). The coral colonies develop at a shallow depth (3-5 m), sedimentation rate is high but lower than at Hormuz Island, and the highest tidal currents among all study sites are found off this island.

\section{Bu-Musa Island}

Bu-Musa Island $\left(25^{\circ} 52^{\prime} \mathrm{N}, 5^{\circ} 02^{\prime} \mathrm{E}\right.$; site $\left.\mathrm{BM}\right)$ is located in the central Persian Gulf. Diving and scientific activities are controlled around this island. Data presented here are integrated from two sites $\left(55^{\circ} 1.3^{\prime} 47^{\prime \prime} \mathrm{E}\right.$, $25^{\circ} 53^{\prime} 22 \mathrm{~N}$ and $\left.55^{\circ} 2^{\prime} 40.32^{\prime \prime} \mathrm{E}, 25^{\circ} 53^{\prime} 47.17^{\prime \prime} \mathrm{N}\right)$ and were collected by snorkeling. Coral communities with low diversity and density are mainly distributed at 2-8 $\mathrm{m}$ depth at both sites. However, only corals at depths of less than $6 \mathrm{~m}$ were studied. Soft corals and zoanthids are rare at these sites.

\section{Survey methods}

Colonies of reef-building corals were recorded using a timed swim method (Hill and Wilkinson 2004). At each study site, an observer swam in a uniform direction parallel to the shore for $60 \mathrm{~min}$ utes (covering an area of approximately $2500 \mathrm{~m}^{2}$ ). Each colony encountered was identified at genus level, and the degree of bleaching was assessed according to the following four categories: 1) fully bleached colonies, which were completely white with no apparent pigmented tissue remaining; 2) mostly bleached corals, with a skeleton more than $50 \%$ white; 3 ) slightly-bleached corals, with a skeleton less than $50 \%$ bare; and 4) healthy corals, with no marked sign of bleaching.

\section{Seawater temperature data}

Biweekly sea surface temperature (SST) data from 2009-2012 were derived from the NOAA Satellite and Information Service (http://www.osdpd.noaa. gov/ml/ocean/sst) to make a multi-year plot of the SST in the area. The same data were used to calculate monthly average SSTs in different years. We could not differentiate temperature conditions among sites owing to the low resolution of the maps. However, the data obtained from the maps for 2012 are consistent with those recorded by dive computers (D9, manufacturer: Suunto with a $1^{\circ} \mathrm{C}$ resolution recording water

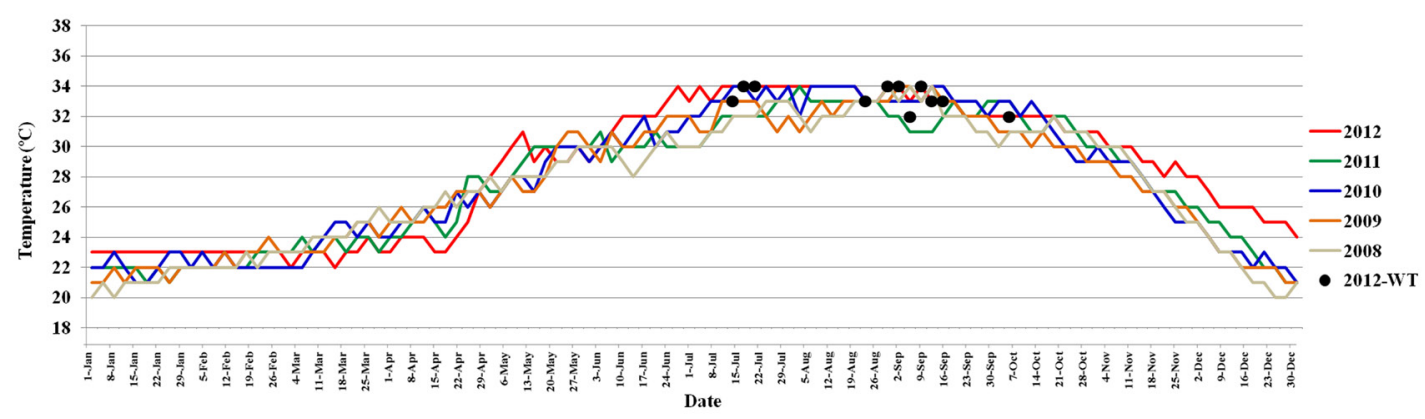

Fig. 2. - Multi-year sea surface temperatures in the study area. Water temperatures recorded by dive computers during the study are shown as 2012-WT. 
temperature every 20 seconds) used during sampling (Fig. 2).

\section{Data analysis}

Contingency table and proportions were used to describe the frequency distribution of each bleaching category for each study site. Moreover, to search for potential differences in bleaching impact across sites and between coral genera we compared proportions of colonies affected by bleaching with a Z test. This test was applied because the number of replications (number of coral colonies) was not similar in comparisons. All statistical analyses were done using SPSS version 16.

\section{RESULTS}

\section{Temperature data}

The multi-year plot of the SSTs in the study area (Fig. 2) clearly showed higher July, August and September temperatures in the region in 2012 than in other
Table 1. - Monthly average sea surface temperatures ( \pm standard deviation) in different years

\begin{tabular}{lccccc}
\hline & 2012 & 2011 & 2010 & 2009 & 2008 \\
\hline July & $33.7 \pm 0.5$ & $31.9 \pm 1.3$ & $32.1 \pm 1.1$ & $32.1 \pm 0.7$ & $31.3 \pm 1.2$ \\
August & $33.8 \pm 0.4$ & $32.4 \pm 0.8$ & $33.6 \pm 0.7$ & $32.6 \pm 0.8$ & $32.6 \pm 1.0$ \\
September & $32.5 \pm 0.5$ & $32.5 \pm 0.5$ & $33.1 \pm 0.6$ & $32.5 \pm 0.9$ & $31.9 \pm 1.2$ \\
\hline
\end{tabular}

years, except for September 2010. Monthly average SSTs were higher in July and August 2012 than in the same months in previous years (Table 1). The SST data obtained in 2012 were coincident with data recorded by dive computers (D9, Suunto) during sampling (Fig. 2 ). For example, if the extracted temperature from the SST maps was $34^{\circ} \mathrm{C}$, the same temperature was recorded on the dive computers at the same time of sampling. Maximum water temperature recorded by the dive computers was 34 to $35^{\circ} \mathrm{C}$ on 22 July.

\section{Dominant community and coral composition of the study sites}

Scleractinian corals were the dominant benthic organisms at all sites except for sites $\mathrm{H}-\mathrm{RS}$ and $\mathrm{H}-\mathrm{S}$,

Table 2. - Coral genera recorded and their bleaching status (in percent) at each site. PS, percentage of each coral genus per site (number of colonies of each genus/number of total colonies counted). Bleaching categories considered: F, fully bleached; M, mostly bleached; S, slightly bleached; H, healthy. * It includes data on Porites, Dipsastraea and Cyphastrea at site Q-SD due to data input complications.

\begin{tabular}{|c|c|c|c|c|c|c|c|c|c|c|c|c|c|c|c|}
\hline \multirow[t]{2}{*}{ Genus } & \multicolumn{5}{|c|}{ H-RS } & \multicolumn{5}{|c|}{ H-E } & \multicolumn{5}{|c|}{ L-NE } \\
\hline & PS & $\mathrm{F}$ & M & $\mathrm{S}$ & $\mathrm{H}$ & PS & $\mathrm{F}$ & M & S & $\mathrm{H}$ & PS & $\mathrm{F}$ & M & $\mathrm{S}$ & $\mathrm{H}$ \\
\hline Acanthastrea & - & - & - & - & - & - & - & - & - & - & - & - & - & - & - \\
\hline Acropora & - & - & - & - & - & - & - & - & - & - & 9.4 & 0 & 2.4 & 66.6 & 31 \\
\hline Coscinaraea & 2.5 & 0 & 0 & 100 & 0 & - & - & - & - & - & - & - & - & - & - \\
\hline Cyphastrea & - & - & - & - & - & - & - & - & - & - & 0.4 & 0 & 0 & 100 & 0 \\
\hline Echinopora & - & - & - & - & - & - & - & - & - & - & - & - & - & - & - \\
\hline Dipsastraea & 24.1 & 100 & 0 & 0 & 0 & 1.9 & 100 & 0 & 0 & 0 & 7.2 & 9.4 & 6.3 & 68.7 & 15.6 \\
\hline Favites & 63 & 81.4 & 0 & 13.7 & 4.9 & - & - & - & - & - & 1.1 & 0 & 20 & 60 & 20 \\
\hline Goniopora & - & - & - & - & - & - & - & - & - & - & 7.4 & 3 & 0 & 97 & 0 \\
\hline Leptastrea & - & - & - & - & - & - & - & - & - & - & - & - & - & - & - \\
\hline Montipora & 1.2 & 0 & 0 & 0 & 100 & - & - & - & - & - & 13.4 & 13.3 & 26.7 & 50 & 10 \\
\hline Pavona & - & - & - & - & - & - & - & - & - & - & - & - & - & - & - \\
\hline Platygyra & - & - & - & - & - & 6.5 & 100 & 0 & 0 & 0 & 6.9 & 0 & 6.5 & 71 & 22.5 \\
\hline Pocillopora & - & - & - & - & - & - & - & - & - & - & 6.3 & 25 & 53.6 & 10.7 & 10.7 \\
\hline Porites & 9.2 & 46.7 & 53.3 & 0 & 0 & 85.1 & 5.1 & 25 & 69.9 & 0 & 33.3 & 7.4 & 10.7 & 73.8 & 8.1 \\
\hline Psammocora & - & - & - & - & - & - & - & - & - & - & 0.4 & 0 & 0 & 50 & 50 \\
\hline Siderastrea & - & - & - & - & - & 6.5 & 71.4 & 28.6 & 0 & 0 & - & - & - & - & - \\
\hline Stylophora & - & - & - & - & - & - & - & - & - & - & 14.2 & 0 & 0 & 28.6 & 71.4 \\
\hline Symphyllia & - & - & - & - & - & - & - & - & - & - & - & - & - & - & - \\
\hline \multirow[t]{3}{*}{ Turbinaria } & - & - & - & - & - & - & - & - & - & - & - & - & - & - & - \\
\hline & \multicolumn{5}{|c|}{ L-SW } & \multicolumn{5}{|c|}{ Q-SD } & \multicolumn{5}{|c|}{$\mathrm{BM}$} \\
\hline & PS & $\mathrm{F}$ & $\mathrm{M}$ & S & $\mathrm{H}$ & PS & $\mathrm{F}$ & $\mathrm{M}$ & S & $\mathrm{H}$ & PS & $\mathrm{F}$ & $\mathrm{M}$ & S & $\mathrm{H}$ \\
\hline Acanthastrea & 0.7 & 50 & 0 & 0 & 50 & - & - & - & - & - & - & - & - & - & - \\
\hline Acropora & 28.5 & 9.1 & 19.4 & 41.6 & 29.9 & - & - & - & - & - & 37.1 & 0 & 50 & 50 & 0 \\
\hline Coscinaraea & - & - & - & - & - & - & - & - & - & - & - & - & - & - & - \\
\hline Cyphastrea & 3.7 & 0 & 20 & 30 & 50 & - & - & - & - & - & - & - & - & - & - \\
\hline Echinopora & 2.2 & 16.7 & 33.3 & 50 & 0 & - & - & - & - & - & - & - & - & - & - \\
\hline Dipsastraea & 16.3 & 22.7 & 22.7 & 31.8 & 22.8 & - & - & - & - & - & 7.6 & 25 & 0 & 0 & 75 \\
\hline Favites & 7 & 26.4 & 21.2 & 26.4 & 26 & 3.2 & 0 & 100 & 0 & 0 & 6.7 & 14.3 & 0 & 0 & 85.7 \\
\hline Goniopora & 5.6 & 53.3 & 13.3 & 33.4 & 0 & - & - & - & - & - & - & - & - & - & - \\
\hline Leptastrea & - & - & - & - & - & 1.8 & 0 & 0 & 0 & 100 & - & - & - & - & - \\
\hline Montipora & 0.4 & 0 & 100 & 0 & 0 & - & - & - & - & - & - & - & - & - & - \\
\hline Pavona & 0.7 & 0 & 50 & 0 & 50 & 0.9 & 0 & 0 & 0 & 100 & - & - & - & - & - \\
\hline Platygyra & 21.9 & 3.4 & 69.5 & 23.7 & 3.4 & 49.4 & 44.9 & 11.2 & 43.9 & 0 & 15.2 & 0 & 0 & 25 & 75 \\
\hline Pocillopora & 1.1 & 100 & 0 & 0 & 0 & - & - & - & - & - & - & - & - & - & - \\
\hline Porites & 10.4 & 14.3 & 17.9 & 42.8 & 25 & - & - & - & - & - & 33.4 & 0 & 5.7 & 0 & 94.3 \\
\hline Psammocora & - & - & - & - & - & - & - & - & - & - & - & - & - & - & - \\
\hline Siderastrea & - & - & - & - & - & - & - & - & - & - & - & - & - & - & - \\
\hline Stylophora & - & - & - & - & - & - & - & - & - & - & - & - & - & - & - \\
\hline Symphyllia & 1.1 & 0 & 0 & 0 & 100 & - & - & - & - & - & - & - & - & - & - \\
\hline Turbinaria & 0.4 & 0 & 0 & 100 & 0 & - & - & - & - & - & - & - & - & - & - \\
\hline Others* & - & - & - & - & - & 44.7 & 15.5 & 23.7 & 30.9 & 29.9 & - & - & - & - & - \\
\hline
\end{tabular}


which were covered by zoanthids. On the other hand, soft coral Sinularia spp. had $31 \pm 7 \%$ coverage of the substratum in some parts (not all) of site L-NE (based on three 50-m line intercept transects), whereas it was rare or absent at other sites. There was no sign of bleaching on the zoanthids and soft corals from Hormuz and Larak Islands. Only four fully bleached colonies of soft corals were observed at Bu-Musa Island.

Although coral diversity at the study sites was low, differences in coral communities and their distribution at the study sites were clear (Table 2). Coral Acropora spp. was only observed at Larak and Bu-Musa Islands. This genus was dominant at Bu-Musa Island and site L-SW, followed by Porites spp. and Platygyra spp., respectively. Porites spp. was dominant at sites L-NE and H-E, whereas Platygyra spp. and Favites spp. were dominant at Q-SD and H-RS, respectively (Table 2).

\section{Coral bleaching data}

\section{Inter-site differences}

Overall data collected from the five sites of the northern Persian Gulf islands (Larak, Hormuz and Qeshm Islands, Fig. 1) showed that about 84\% of 1309 counted colonies were affected by bleaching in 2012 (Fig. 3). The most impacted corals were recorded at site H-E, where no healthy coral was recorded, followed by H-RS, where $96 \%$ of the corals were bleached and $80 \%$ fully bleached (Fig. 3). The least impacted corals (with only about $12 \%$ of colonies displaying bleaching) were recorded at Bu-Musa Island. Detailed information is shown in Figure 3 for all sites. There were significant differences $(\mathrm{p}<0.05)$ between sites in percentage of healthy colonies (except for L-NE and L-SW; Z=0.3, $\mathrm{p}>0.05$ ) and fully bleached colonies (except between $\mathrm{H}-\mathrm{E}$ and Q-SD; Z=0.457, $\mathrm{p}>0.05$ ).

\section{Inter-genus differences}

Dipsastraea (formerly Favia; see Budd et al. 2012) and Platygyra colonies from Hormuz Island were the only genera of all colonies that were fully bleached (Table 2). Some other genera (e.g. Platygyra, which was dominant at site Q-SD) showed strong bleaching with no recorded healthy colony (Table 2 ). The highly susceptible branching coral, Acropora spp., showed different responses at Bu-Musa Island and Larak Island. All observed Acropora colonies at Bu-Musa Island were affected by bleaching, in contrast with Porites spp., which had about $94 \%$ healthy colonies. However, at Larak Island Acropora spp. displayed a higher percentage of healthy and/or a lesser percentage of fully bleached colonies than massive Porites (Table 2). For example, at site L-NE $31 \%$ all recorded Acropora spp. colonies were healthy, with no fully bleached colonies, which was significantly different $(\mathrm{p}<0.05 ; \mathrm{Z}=5.12$ for healthy corals and $\mathrm{Z}=2.89$ for fully bleached corals) from about $7 \%$ healthy and $8 \%$ fully bleached colonies for Porites spp. Although these differences were not statistically significant for site L-SW ( $>0.05 ; Z=0.75$ for healthy corals and $\mathrm{Z}=-1.11$ for fully bleached corals), the percentage of

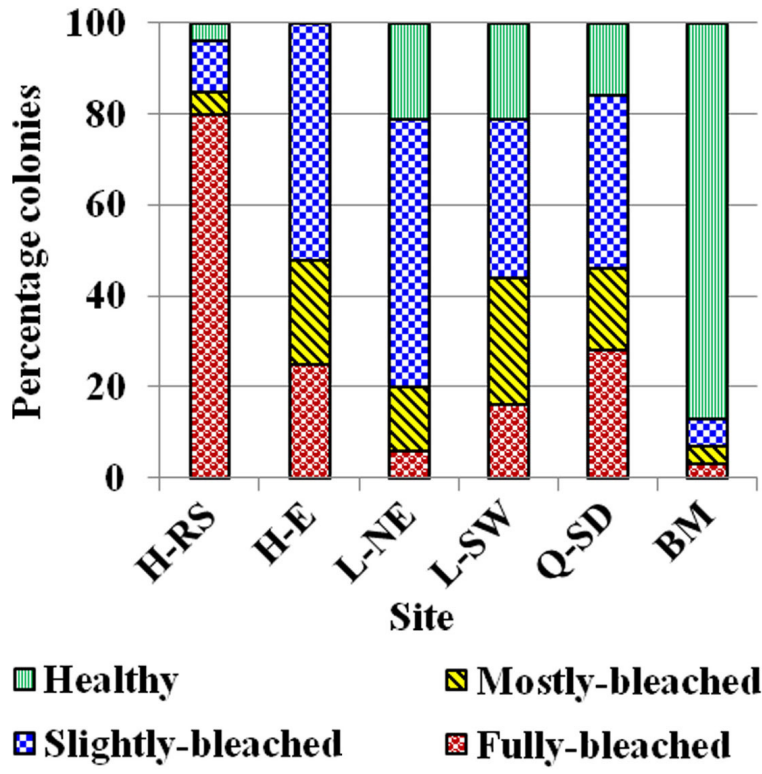

Fig. 3. - Percentage of fully bleached, mostly bleached, slightly bleached, and healthy corals at each site. Abbreviations: H-RS, southern site of Hormuz Island; H-E, eastern site of Hormuz Island; L-NE, northeastern site of Larak Island; L-SW, southwestern site of Larak Island; Q-SD, southern site of Qeshm Island; BM, Bu-Musa Island

colonies affected at different levels varied (30\% healthy and $9 \%$ fully bleached colonies for Acropora and $25 \%$ healthy and $14 \%$ fully bleached colonies for Porites). The branching coral Stylophora was observed at site L-NE with $71 \%$ healthy colonies and no fully or mostly bleached colonies (significant differences $\mathrm{p}<0.05$; with both Porites $[\mathrm{Z}$ value $=9.28$ for healthy corals and -2.69 for bleached corals] and Acropora spp. colonies [Z val$\mathrm{ue}=4.82]$ except in comparison between fully-beached Acropora and Stylophora, for both of which the value was zero).

Unlike the predominant genera, which were more affected by the bleaching, less common genera recorded in the area, including Montipora from site H-RS, Symphyllia spp. from L-SW, Pavona and Leptastrea spp. from Q-SD, with 2-4 recorded colonies, were not affected by the bleaching. However, there were some exceptions: for example, all Montipora spp. corals, including $0.4 \%$ of all colonies counted at site L-SW, were mostly bleached (Table 2).

\section{DISCUSSION}

The 2012 coral bleaching in the northern Persian Gulf, including Larak, Hormuz and Qeshm Islands, had a great incidence, affecting about $84 \%$ of the coral colonies surveyed. Monthly average SSTs were warmer in 2012 than in previous years (Table 1). Although SSTs are not always an accurate indicator of changes in temperature in submerged coral reefs because of significantly cooler temperatures in deeper waters (Sheppard 2009), shallow depth (3 to $5 \mathrm{~m}$ during the study), and high wave and tidal current mixing of the surface and bottom waters, there were almost no differences between SSTs and seabed temperatures based on in situ data recorded by dive computers (Fig. 2). 

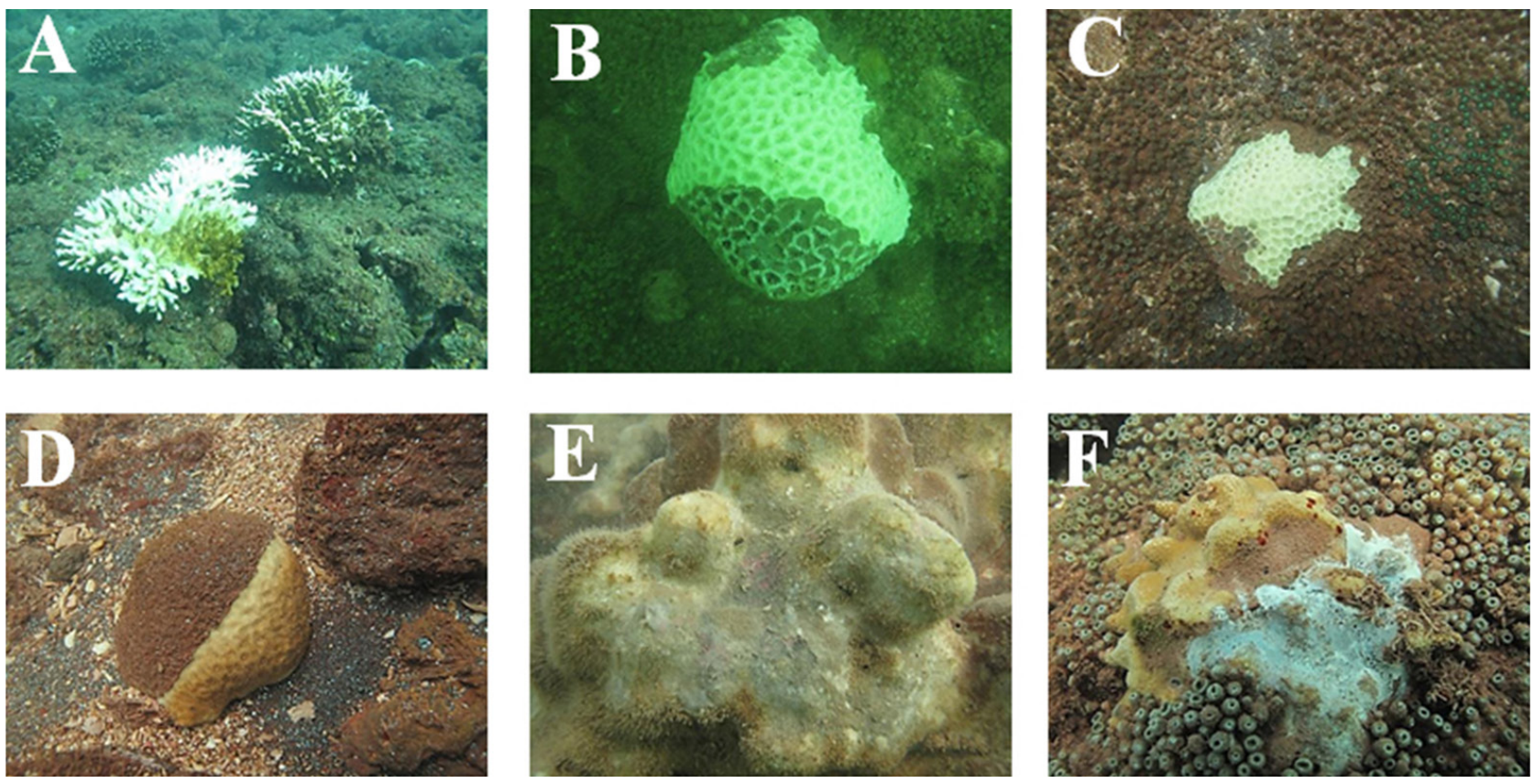

Fig. 4. - Post-bleaching feature of corals and environmental conditions. Algal overgrowth on bleached Acropora at site L-SW (A); tissue loss due to high sedimentation on a bleached but still alive Dipsastraea colony at site H-RS (B); a bleached Favites colony among live zoanthids becoming covered by fine organic rich sediments at site H-RS (C); a partially dead Coscinaraea colony owing to high settlement of fine sediments at site H-RS (D); a Porites colony invaded by White Mat Disease becoming overgrown by filamentous algae (E); a Porites colony invaded by White Mat Disease becoming overgrown by macroalgae, zoanthids and sediment settlement at site H-E (F).

Although Coles and Riegl (2013) mentioned 35 to $36^{\circ} \mathrm{C}$ as a coral bleaching threshold temperature in the Persian Gulf, the coral bleaching threshold temperature in the northern Persian Gulf is likely $1.5^{\circ} \mathrm{C}$ to $2.5^{\circ} \mathrm{C}$ lower. Cooler waters, higher water circulation, connection to the Straits of Hormuz and fewer disturbances have been suggested as explanations for different maximum average summer temperatures (Thoppil and Hogan 2010) and probably for different coral bleaching threshold temperatures in the southern and northern Persian Gulf.

The 2012 bleaching event described in this study was concomitant with temperature highs of $34^{\circ} \mathrm{C}$ on many days over an approximate one-and-a-half-month period (Fig. 2), resulting in massive coral bleaching at all study sites in the northern Persian Gulf (Fig. 3). Kavousi et al. (2011) reported that reef-building corals of Qeshm Island experienced $33^{\circ} \mathrm{C}$ temperatures in August and September 2009 with no bleaching event. These temperature conditions coincided with SST data in this study and show that from late July to mid-September temperatures were about $33^{\circ} \mathrm{C}$ on the majority of days (Fig. 2).

In contrast with 2012, monthly average SSTs at our study area in August and September 2010 were 1 and $0.6^{\circ} \mathrm{C}$ higher than the highest temperatures in the same months of other years (Table 1), but no coral bleaching was reported in the northern Persian Gulf whereas more than $60 \%$ of corals in the southern and central parts were bleached (Riegl et al. 2011). Field observations at Larak Island during the summer and autumn of 2010 confirmed that there was no massive bleaching, but there were three partially-bleached colonies and a few colonies with discolouration were recorded (Parviz Tavakoli-Kolour, personal observation). Temperature anomalies based on the monthly average temperatures were probably 1.6 and $1.2^{\circ} \mathrm{C}$ for July and August 2012, with no anomaly for September (Table 1).

A comparison among monthly average temperatures (Table 1) suggests that the threshold monthly average temperature was about $33.8^{\circ} \mathrm{C}$ at our study sites. This finding is based on using the minimum monthly average temperature at which bleaching happened $\left(33.8^{\circ} \mathrm{C}\right.$ in 2012$)$ compared with the maximum monthly average temperatures at which it did not $\left(33.6^{\circ} \mathrm{C}\right.$ in September 2010 and $33.7^{\circ} \mathrm{C}$ in July 2012; Parviz Tavakoli-Kolour, personal observation). However, the 2012 bleaching in the northern Persian Gulf could be because of the longer duration of the 2012 temperature anomaly than in 2010 (two months and one month, respectively). Therefore, it is difficult to suggest an exact temperature as the possible bleaching threshold temperature for corals in the northern Persian Gulf in this study owing to a lack of precise temperature data; however it is probably a temperature between 35.5 and $34^{\circ} \mathrm{C}$. It should be noted that temperature records correspond to discrete measurements from SST data and future studies should obtain high temporal resolution data using autonomous temperature data loggers.

The 2012 coral bleaching event bleached more than $84 \%$ of coral colonies observed in this study in the northern Persian Gulf, but only $12 \%$ of corals recorded from Bu-Musa Island located in the central gulf (Fig. 3; significant difference $\mathrm{p}<0.05$ ). There was no major bleaching, but discolouration of a few colonies was observed in the southern part of the Persian Gulf (Dr. John Burt, Personal communication). Therefore, 
the northern Persian Gulf was warmer than the southern part (spatial heterogeneity) in 2012 and in 2007 (Wilkinson 2008).

In general, previous bleaching reports have indicated that massive corals tend to have higher survival from thermal stress, especially Porites (Goreau et al. 2000) Favia, Favites and Platygyra (Loya et al. 2001, McClanahan 2004). This contrasts with branching corals, which are among the most vulnerable to thermal stress (Goreau et al. 2000, Loya et al. 2001, McClanahan 2004). Although the bleaching pattern at Bu-Musa Island was coincident with the above information, branching Acropora and Stylophora recorded at Larak Island were less affected by the bleaching than massive Porites (Table 2).

Miller et al. (2011) also reported no bleaching for Acropora palmata at Navassa Island in 2006, whereas other corals studied, including massive corals, were severely bleached. Guest et al. (2012) reported the same phenomenon (more tolerance of susceptible taxa than massive corals) in extremely muddy waters from Singapore. They concluded that it was an adaptive response to anomalous temperatures, but it is difficult to say whether this was because of acclimatization to elevated temperatures or adaptation via more thermally tolerant genotype selection of coral populations (van Woesik et al. 2012) or simply the well-known higher survival rate of these corals in turbid environments (Goreau et al. 2000).

Turbid waters have been noted to reduce coral mortality in severe bleaching events because solar irradiance acts to amplify thermal stress (Goreau et al. 2000, Takahashi et al. 2004, Golbuu et al. 2007, Wagner et al. 2010). However, previous studies have also suggested that turbid-water corals are more vulnerable to local and global stresses (Fabricius et al. 2007, 2008).

The highest incidence of bleaching colonies in this study was found in more turbid waters (about $3 \mathrm{~m}$ deep). The most turbid waters were around H-RS, where $80 \%$ of corals were fully bleached. Turbid waters can provide protection from light stress during high-temperature bleaching events (Goreau et al. 2000), but in view of our results they may not be a coral refugium against thermal stress and post-bleaching stresses (Fig. 4).

The synergic effects of other factors with temperature conditions are also illustrated by the onset of diseases during and after bleaching events. For instance, Porites colonies, which comprise about $85 \%$ of all coral cover at site H-E, were mostly infected by a White Mat Disease that is a result of sediment-microbial interactions (Kavousi et al. 2013). There may be a link between elevated SSTs and outbreak of the White Mat Disease (Fig. 4E, F), as this disease killed about $60 \%$ of Porites live tissue at site H-E during the 2012 temperature anomaly (Kavousi et al. 2013).

Dominant coral genera at a majority of our study sites were among those most affected in the 2012 coral bleaching event. The same results were reported by Dalton and Carroll (2011) at high-latitude eastern Australian reefs. This may be an artifact of the low diversity of these sites, and the fact that the more vulnerable coral colonies may have been previously killed in prior bleaching events, leaving behind the more tolerant colonies. In 1998 many Acropora-dominated reefs in the Indian Ocean and Pacific lost almost all their Acropora and wound up being dominated by Porites survivors (Goreau et al. 2000). A similar situation was observed at L-NE but some factors besides bleaching were involved (Mohammadizadeh et al. 2013). The 2012 bleaching may change the dominant coral genera at our study sites in the coming years, especially at sites that were severely affected. Although this bleaching event may not cause local extinction of coral genera, as occurred in the southern Persian Gulf in 1996 (Riegl 2002, Sheppard 2006) and probably at Qeshm Island in 2007 (Kavousi et al. 2011), long-term monitoring programmes are needed because post-bleaching events are sometimes more severely destructive (e.g. Bastidas et al. 2012, Fig. 4).

\section{ACKNOWLEDGEMENTS}

We thank Dr. T. Goreau, Dr. T. Nakamura, Dr. J. Reimer and Dr. J. Burt for improving the manuscript with their useful comments. We are also grateful for the helpful comments of the anonymous reviewers. Thanks to Professor G. MacLean for final English editing.

\section{REFERENCES}

Baker A.C., Starger C.J., McClanahan T.R., et al. 2004. Corals' adaptive response to climate change. Nature 430: 741. http://dx.doi.org/10.1038/430741a

Bastidas C., Bone D., Croquer A., et al. 2012. Massive hard coral loss after a severe bleaching event in 2010 at Los Roques, Venezuela. Rev. Biol. Trop. 60: 29-37.

Buchheim J. 2005. Coral reef bleaching. Journal of Odyssey Expeditions, Tropical Marine Biology Voyages, $10 \mathrm{pp}$.

Budd A.F., Fukami H., Smith N.D., Knowlton N. 2012. Taxonomic classification of the reef coral family Mussidae (Cnidaria: Anthozoa: Scleractinia). Zool. J. Linn. Soc. 166: 465-529. http://dx.doi.org/10.1111/j.1096-3642.2012.00855.x

Burt J., Al-Harthi S., Al-Cibahy A. 2011. Long-term impacts of coral bleaching events on the world's warmest reefs. Mar. Environ. Res. 72: 225-229. http://dx.doi.org/10.1016/j.marenvres.2011.08.005

Coles S.L., Brown B.E. 2003. Coral bleaching-capacity for acclimatization and adaptation. Adv. Mar. Biol. 46: 183-223. http://dx.doi.org/10.1016/S0065-2881(03)46004-5

Coles S.L., Riegl B.M. 2013. Thermal tolerances of reef corals in the Gulf: A review of the potential for increasing coral survival and adaptation to climate change through assisted translocation. Mar. Pollut. Bull. 72: 323-332. http://dx.doi.org/10.1016/j.marpolbul.2012.09.006

Dalton S.J., Carroll A.G. 2011. Monitoring coral health to determine coral bleaching response at high latitude eastern Australian reefs: an applied model for a changing climate. Diversity 3 : 592-610. http://dx.doi.org/10.3390/d3040592

Fabricius K.E., Hoegh-Guldberg O, Johnson J., et al. 2007. Vulnerability of coral reefs of the Great Barrier Reef to climate change. In: Johnson J.A., Marshall P.A. (eds), Climate change and the Great Barrier Reef: a vulnerability assessment. The Great Barrier Reef Marine Park Authority, Townsville, pp. 515-554.

Fabricius K.E., De'ath G., Puotinen M., et al. 2008. Disturbance gradients on inshore and offshore coral reefs caused by severe tropical cyclone. Limnol. Oceanogr. 53: 690-704. http://dx.doi.org/10.4319/10.2008.53.2.0690

Golbuu Y., Victor S., Penland L., et al. 2007. Palau's coral reefs show differential habitat recovery following the 1998-bleaching event. Coral Reefs 26: 319-332.

http://dx.doi.org/10.1007/s00338-007-0200-7

Goreau T.J., Hayes R.L. 1994. Coral bleaching and ocean hot spots. 
Ambio 23: 176-180.

Goreau T.J., Hayes R.L. 2005. Global coral reef bleaching and sea surface temperature trends from satellite-derived Hotspot analysis. World Resource Rev. 17: 254-293.

Goreau T., McClanahan T., Hayes R., et al. 2000. Conservation of coral reefs after the 1998 global bleaching event. Conserv. Biol. 1: $5-15$. http://dx.doi.org/10.1046/j.1523-1739.2000.00011.x

Goreau T.J., Hayes R.L., McAllister D. 2005. Regional patterns of sea surface temperature rise: implications for global ocean circulation change and the future of coral reefs and fisheries. World Resource Rev. 17: 350-374.

Guest J.R., Baird A.H., Maynard J.A., et al. 2012. Contrasting patterns of coral bleaching susceptibility in 2010 suggest an adaptive response to thermal stress. PLoS One 7: e33353. http://dx.doi.org/10.1371/journal.pone.0033353

Hill J., Wilkinson C. 2004. Methods for ecological monitoring of coral reefs. Australian Institute of Marine Science, Townsville, $117 \mathrm{pp}$.

Kavousi J., Seyfabadi J., Rezai H., et al. 2011. Coral reefs and communities of Qeshm Island, the Persian Gulf. Zool. Stud. 50: 276-283.

Kavousi J., Tavakoli-Kolour P., Barkhordari A., et al. 2013. Mass mortality of Porites corals on northern Persian Gulf reefs due to sediment-microbial interactions. Int. J. Mar. Sci. 3: 306-310.

Lesser M.P. 2011. Coral Bleaching: Causes and Mechanisms. In: Dubinksy Z., Stambler N. (eds), Coral Reefs: an ecosystem in transition. Springer Science, New York, pp. 405-419.

Loya Y., Sakai K., Yamazato K., et al. 2001. Coral bleaching: the winners and the losers. Ecol. Lett. 4: 122-131. http://dx.doi.org/10.1046/j.1461-0248.2001.00203.x

McClanahan T.R. 2004. The relationship between bleaching and mortality of common corals. Mar. Biol. 144: 1239-1245. http://dx.doi.org/10.1007/s00227-003-1271-9

Meissner K.J., Lippmann T., Sen Gupta A. 2012. Large-scale stress factors affecting coral reefs: open ocean sea surface temperature and surface seawater aragonite saturation over the next 400 years. Coral Reefs 31: 309-319. http://dx.doi.org/10.1007/s00338-011-0866-8

Miller M.W., Piniak G.A., Williams D.E. 2011. Coral mass bleaching and reef temperatures at Navassa Island, 2006. Est. Coast. Shelf Sci. 91: 42-50. http://dx.doi.org/10.1016/j.ecss.2010.10.005

Mohammadizadeh M., Tavakoli-kolour P., Rezai H. 2013. Coral reefs and community around Larak Island (Persian Gulf). Caspian J. Appl. Sci. Res. 2: 52-60.

Rezai H., Wilson S., Claereboudt M., et al. 2004. Coral reef status in the ROPME Sea area, Arabian/Persian Gulf, Gulf of Oman and Arabian Sea. In: Wilkinson C. (ed), Status of coral reefs of the world. Vol. 1. Australian Institute of Marine Science, Townsville, Queensland, pp. 155-170.

Rezai H., Kamrani E., Samimi-Namin K., et al. 2010. Coral degradation, distribution and abundance around Larak, Hengam and
Kish Islands, Persian Gulf. Iranian National Centre for Oceanography, Tehran.

Riegl B. 2002. Effects of the 1996 and 1998 positive sea surface temperature anomalies on corals, coral diseases and fish in the Arabian Gulf (Dubai, UAE). Mar. Biol. 140: 29-40.

http://dx.doi.org/10.1007/s002270100676

Riegl B., Purkis S. 2009. Model of coral population response to accelerated bleaching and mass mortality in a changing climate. Ecol. Model. 220: 192-208. http://dx.doi.org/10.1016/j.ecolmodel.2008.09.022

Riegl B.M., Purkis S.J. (eds). 2012. Coral reefs of the Gulf (Vol. 3). Springer DE, Germany, 250 pp. http://dx.doi.org/10.1007/978-94-007-3008-3

Riegl B.M., Purkis S.J., Al-Cibahy A.S., et al. 2011. Present limits to heat-adaptability in corals and population-level responses to climate extremes. PLoS One 6: e24802. http://dx.doi.org/10.1371/journal.pone.0024802

Sheppard C.R.C. 2003. Predicted recurrences of mass coral mortality in the Indian Ocean. Nature 425: 294-297. http://dx.doi.org/10.1038/nature01987

Sheppard C.R.C. 2006. Longer term impacts of climate change. In: Cote I., Reynolds J. (eds), Coral Reef Conservation. Cambridge University Press, Cambridge, pp. 264-290. http://dx.doi.org/10.1017/CBO9780511804472.010

Sheppard C.R.C. 2009. Large temperature plunges recorded by data loggers at different depths on an Indian Ocean atoll: comparison with satellite data and relevance to coral refuges. Coral Reefs 28: 399-403. http://dx.doi.org/10.1007/s00338-009-0476-x

Sheppard C.R.C., Price P., Roberts C. 1992. Marine ecology of the Arabian region. Academic Press, London, 359 pp.

Takahashi S., Nakamura T., Sakamizu M., et al. 2004. Repair Machinery of symbiotic photosynthesis as the primary target of heat stress for reef-building corals. Plant Cell Physiol. 45: 251-255. http://dx.doi.org/10.1093/pcp/pch028

Thoppil P.G., Hogan P.J. 2010. A modeling study of circulation and eddies in the Persian Gulf. J. Phys. Oceanogr. 40: 2122-2134. http://dx.doi.org/10.1175/2010JPO4227.1

Wagner D.E., Kramer P., van Woesik R. 2010. Species composition, habitat, and water quality influence coral bleaching in south-eastern Florida. Mar. Ecol. Prog. Ser. 408: 65-78. http://dx.doi.org/10.3354/meps08584

Wilkinson C. 2004. Status of Coral Reefs of the World. Australian Institute of Marine Science, Townsville.

Wilkinson C. 2008. Status of Coral Reefs of the World: 2008. Australia: Global Coral Reef Monitoring Network and Reef and Rainforest Research Center, Townsville.

van Woesik R., Houk P., Isechal A.L., et al. 2012. Climate-change refugia in the sheltered bays of Palau: analogs of future reefs. Ecol. Evol. 2: 2474-2484 http://dx.doi.org/10.1002/ece3.363 